\title{
Accounting and sustainable development: reflections and propositions
}

\author{
Jan Bebbington; ${ }^{\mathrm{a}}$ Shona Russell ${ }^{\mathrm{a}} \&$ Ian Thomson $^{\mathrm{b}}$
}

a: The School of Management, the University of St Andrews, North Haugh, St Andrews, KY16 9SS, Scotland, United Kingdom. E-mail: jan.bebbington@standrews.ac.uk and shona.russell@st-andrews.ac.uk.

b: The Department of Accounting, University of Birmingham, Edgbaston,

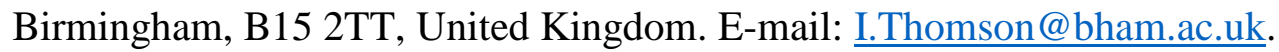
Corresponding author: Jan Bebbington. Tel@ + 441334462 348; fax: + 441334462 812. E-mail address: jan.bebbington@st-andrews.ac.uk.

\begin{abstract}
This paper emerges from an invitation to reflect upon the achievements of social and environmental accounting as well as to identify the challenges that lie ahead as the field continues its engagement with the goal of sustainable development. Three perspectives are developed in pursuit of that aim, namely: exploring the nature of the issues and mode of academic inquiry that is 'fit for purpose' given the demands of sustainable development; considering if a de-centring of accounting and the embrace of more holistic versions of accountability would be productive for future scholarship; and an exploration of how we might conceptualise 'engagement' with practice in this context (and what is meant by practice and practitioner). Taken together, this paper seeks to provide points of provocation and encouragement to social and environmental accountants, critical accounting scholars and to those seeking to understand sustainable development scholarship and action.
\end{abstract}

Keywords: Accountability; sustainable development.

\section{Highlights:}

- Social and environmental accounting scholarship has a track record in engaging with sustainable development concerns but there remain many avenues for its further development 
- Sustainable development concerns are sufficiently wide and complex that a focus on accountability settings (rather than solely on accounting itself) will likely be beneficial for field development

- Being explicit about theorising what might emerge from engagement with practice is likely to advance social and environmental accounting scholarship

\subsection{Introduction}

This paper provides an individual and collective reflection on social and environmental accounting (SEA): the original framing of a literature concerned with the social and environmental impacts of organisations and accounting (Gray, Bebbington \& Gray, 2010; Gray, Owen \& Adams, 1996; Gray, Owen \& Maunders, 1987). ${ }^{1}$ This subject area has more recently broadened to examine the intersection between sustainable development, governing, organising, managing and accounting (Bebbington, Larrinaga, Russell \& Stevenson, 2015; Bebbington \& Larrinaga, 2014; Bebbington \& Thomson, 2013; Gray, 1992; 2002; 2010; Hopwood, 2009; Hopwood, Unerman \& Fries 2010; Russell \& Thomson, 2009; Spence \& Rinaldi 2014;

Thomson, Grubnic \& Georgakopoulos 2014; Unerman \& Chapman, 2014) with this greater breadth having conceptual and methodological implications as well as implications for engagement with practice. These implications form the basis for our conjectures as to how this area of scholarship and practice might develop in the future. For clarity, we conceptualise scholarship as activities undertaken by 'the academy', including research (of which a subset might be published), teaching and working alongside those outside of the academy. In contrast, we understand practice as referring to activities undertaken by those outside of the academy, which could include the accounting profession, policy makers, organisations (both public and private sector) and NGOs. While recognising that practice and practising may be understood as spanning a common-sense-view of what people do through to detailed theoretical understandings of social life (Schatzki, 2012), our use of the term recognises that knowledge and action are produced and operationalised by academics

\footnotetext{
${ }^{1}$ Social and environmental accounting draws on earlier motifs in business literature (Bowen, 1953), but can more recently be traced to the interpretive and critical 'turn' (Chua, 1986) in accounting which dates from approximately the 1970s. Consideration of social issues emerged earlier than those of the environment; which came to the fore in the early 1990s. Our own engagement with the field can be dated to the early 1990s (Bebbington and Thomson) and early 2000s (Russell).
} 
and in concert with others. The complexities and nuance that will emerge from these distinctions and dynamics of each will be considered as the paper progresses.

Some opening observations about the authorship of the paper and the approach taken are pertinent. Reflective pieces in journals are often contributed by longstanding participants in a field. We were keen, however, to contribute a more diverse collective reflection for two reasons. First, developing a literature is invariably a social activity whereby ideas emerge from interactions between co-authors as well as members of a scholarly community (indeed all co-authors have benefited from and contributed to the Centre for Social and Environmental Accounting Research - hereafter CSEAR). As such, a collective reflection seemed apposite and also illuminates subtleties within the themes explored in the paper (see also Gray \& Laughlin, 2012; Guthrie \& Parker, 2017). Second, reflections are usually solicited from individuals who are seen to be long standing in a field, which two of us (Bebbington and Thomson) can't deny. It is less common to solicit reflections from those who are at an earlier stage in their career. ${ }^{2}$ We hope that the opening up of dialogue to include a mid-career academic (Russell) will provide greater breadth of reflection.

The paper takes the form of an 'appreciative enquiry', ${ }^{3}$ following the inspiration of Ghaye, Melander-Wikman, Kisare, Chambers ... \& Lillyman (2008: 362) who suggest that "[d]eficit phrased questions lead to deficit-based conversations ... [which] in turn lead to deficit-based actions". Indeed, we seem to live in a world where dismissing of the views of others and belittling people is increasingly commonplace. Likewise, a particular version of academic inquiry and conduct encourages and champions antagonism towards competing views (beyond that required to enhance scholarship) rather than an active co-development of knowledge and understanding (an agonistic framing if you like - see Brown \& Dillard, 2013a and Dillard \& Brown, 2012; 2015). Further, as Freirean inspired scholars (Thomson \& Bebbington, 2004; 2005) we are not convinced that absolute certainty that one is right

\footnotetext{
2 This approach, however, is increasingly common amongst doctoral and early career researchers. See for example, Raineri (2015) for a discussion of undertaking an accounting PhD in North America; Patterson, Lukasiewicz, Wallis, Rubenstein ... \& Lynch (2013) with regard to early career researchers' experiences of water governance research; and efforts to create opportunities for collective action in increasingly uncertain academic climates - NZGS-PG Network (2014).

${ }^{3}$ We often believe that we know what doesn't work in any particular setting. Appreciative inquiry seeks to understand what does work and what might work in the future with sufficient effort and vision.
} 
is warranted (at least not on our behalf) nor necessary. Being open to not knowing, to seeing the logic in others' arguments and to changing one's mind can be a strength. At times the academy appears to be designed to encourage us to emphasise certainty and disagreement rather than to acknowledge uncertainty about positioning. In this piece of work we are trying not to fall into certainty and have taken to heart Alvesson \& Spicer's (2012: 1213) elaboration of the perils of functional stupidity that they characterise as emerging "from the interplay between unwillingness and a (learned) incapacity to engage in reflexivity, a partial closing of the mind, freezing of the intellectual efforts, a narrowed focus, and an absence of requests for justification”.

Finally, including this reflection in Critical Perspectives on Accounting is appreciated because there is a productive tension between social/environmental/sustainability and critical accounting scholars who are often motivated by similar concerns as well as sharing some of the techniques (for example, social audit - see Cooper, Taylor, Smith, \& Catchpowle, 2005). Of course, kinship is not comfortable (and nor should it be) as there are substantive differences in beliefs concerning the relative role of structure and agency, in theoretical commitments and in the degree to which collaborating alongside practice may be productive or advisable. In particular, we believe that epistemological differences in these two fields reflect different beliefs of how society operates, theories of change and possibilities for emancipation (some of these points of difference will resurface in this paper). As a result, each scholarly 'project' provides a moment of reflection on the other.

With these opening points made, the paper is structured in three parts. First, reflections on our motivations for being a part of an accounting and sustainable development nexus are developed. Second, three themes are explored in order to suggest possible future elements of accounting for sustainable development, namely:

(i) outlining the 'problem space' in which accounting for sustainable development emerges; (ii) an exploration of accountability as a way to framing research, rather than solely focusing on the techniques of accounting; and (iii) exploring issues arising from engagement with practice and policy. Finally, some concluding comments will be made.

\subsection{Motivations: that is, a reason for acting or behaving in a particular way}




\subsection{Bebbington}

Origins: motivations are rarely entirely clear in real time and are, perhaps, unreliable in hindsight when they are conditioned by career path-dependency. Nevertheless, it is useful to recall why one would expend time and energy on a course of action as well as articulating a conception of change in conjunction with these efforts. In brief, I accidentally fell into SEA while backing away from a chartered accounting career in financial audit and tax avoidance ${ }^{4}$. In 1990 I was halfway through a Masters in Commerce degree at the University of Canterbury in New Zealand when Rob Gray visited and opened my eyes to SEA. The existence of SEA and the possibility of being involved in such a field was a revelation to me and I was hooked.

While there are many avenues for contributing to the broader sustainable development agenda, my rationale for doing this via the academy arises from a desire to put scholarship at the heart of my working life. For me, there are three personal motivations that fit with this choice. First, education is core to the role of the academy in society. While education is never sufficient on its own, educating future accountants, managers and citizens about sustainable development challenges, how these challenges have come to pass, whose interests are privileged in the problem space and how 'better' outcomes might be pursued seems a necessary activity if there are any possibilities for change. For example, Orr (2004: 26) notes those "now being educated will have to do what we, the present generation, have been unable or unwilling to do". This is not to say that there are not pressures as higher education moves to a payment based model where learning becomes more instrumental and organisations more managerial (these tendencies vary considerably across the globe and between institutions). I recognise the benefits of working in a School of Management that does not focus on 'supplying' accounting graduates and also in a country (Scotland) where not all students are paying fees. Further, Burawoy (2005: 7) reminds us that our students are our "first and captive public" and as scholars we have a duty to engage them in our programmes of work. As such, for me the classroom

\footnotetext{
${ }^{4}$ My experience of taxation led me to leave accounting as a career as I couldn't accept the legal (but to my eyes immoral) ways in which I was asked to conduct myself. I am delighted to see debates around tax avoidance more recently regaining salience.
} 
constitutes a central location where I engage in conversations about accounting and its role in society (see Loads \& Campbell, 2015, who explore authentic, transformative and disruptive approaches to academic development and Saravanamuthu, 2015, for an accounting education case study).

Second, undertaking research provides a chance to understand the root causes of situations rather to have to focus on addressing the symptoms (as many of those in practice have to do). This motivation is aligned with a perceived authority to link academic expertise and insight to broader processes of change - through policy making, contributing to societal debates, engaging in collaborations with scholars in other fields as well as working alongside institutions (such as the accounting profession) and organisations that are seeking to change what they do. The complexity of engaging with practice and policy is further discussed later in this paper.

Third, working in organisations (universities) that are relatively open to employee influence (and who have their own economic, environmental and social effects) creates a possibility for academics to contribute to institutional activities in research, teaching/learning and external engagement as well as working to make campuses more sustainable (Godermann, Bebbington, Herzig \& Moon, 2014; Hugé, Block, Waas, Wright \& Dahdouh-Guebas, 2016, but also see Bebbington, 2016). For example, I have worked (in partnership with many others) to support my current institution's goals to be a 'carbon neutral' university as well as being involved in other sustainable development related work (for example, agitating for the payment of a living wage to all staff). These activities are informed by my academic reading and is (for me) a critical part of my activism.

Models of change: I have also sought to articulate a model of change for my own agency in these wider systems: in education; in policy; as an employee and as an advocate/advisor to selected organisations. ${ }^{5}$ Provisionally, my views about a model of change include, first, a belief that chains of cause and effect are complex and often the impact of any one input to a process is not clear. This has led me to an interest in

\footnotetext{
${ }^{5}$ I found the idea of governmentality, as translated by Dean (1999), to be of practical use in these roles.
} 
wicked and post normal theories as well as sustainability science - Bebbington \& Larrinaga (2014) is my best current articulation of these interests. Second, change of any substantive character is invariably programmatic. That is, any one intervention (no matter how powerful or insightful) is not going to generate change on its own. Rather, repeat interventions over time as well as interventions from more than one source might come to something (with timing sometimes being critically important). Related to this, if you see them at all, it can be some time before you see an outcome from your efforts. Likewise, change (in a perceived positive direction) can also be undone and regression is always a possibility. Third, I would suggest that the hunting for the root causes of effects creates the possibility that one might find leverage points in the 'system' to enact change, although this type of work is often slow and not very glamorous. For example, rewriting building regulations so that recycled aggregate can be used in new builds (if it reaches certainly quality standards and determining metrics for these standards) is necessary but not exciting work: it is, however, an element to developing a lower carbon built environment.

These observations on change have been developed (and tested) when I spent a decade in various formal policy roles (as a Member of the Scottish Executive Cabinet Sub-Committee on Sustainable Scotland and as the Vice Chair (Scotland) of the Sustainable Development Commission). Both of these roles involved direct and sustained interaction with politicians as well as civil servants and covered a variety of topics including: climate change; waste policy; carbon evaluation of transport infrastructure; food and drink policy; education for sustainable development and formal holding of Government to account on their sustainable development programmes. ${ }^{6}$ This work persuaded me that before accounting scholarship can effect change the context in which we hope accounting will find traction needs to be appreciated in all its complexity. For example, carbon accounting proposals need to be understood in the context of global climate change science, politics and governance. Accounting scholarship (in my view) works 'best' when it takes complexity on board.

\footnotetext{
${ }^{6}$ Cooper (2005) has much to say about public intellectuals and, while I would not claim to have been one, her work was insightful as I sought to navigate the roles I found myself in.
} 
In the Sustainable Development Commission role I also had to undertake numerous keynote speeches to the widest possible range of public, private and third sector organisations articulating what sustainable development might mean to their communities of practice. Finding new ways to engage often sceptical audiences was challenging. From time to time I would present the 'classic' accountability outline (see Gray et al., 1987; 1996) and was surprised by how interested audiences were in accountability. Invariably people I engaged with over this time were also amazed that, as an accountant, I had something to bring to these broader topics - something I suspect accountants themselves often forget. In Burawoy's (2005) terms, this could be evidence that the accounting discipline needs to be self-consciously more visible to the public.

In addition, this extended period of policy work made in-discipline 'normal' science investigations much less appealing. I have become convinced of the need to study social, environmental and economic phenomena and then to look for the accounting influence rather than start with the accounting and keep it at the centre of one's focus. I also had to become comfortable with the fact that in most rooms I was the least qualified person in the particular topic we were discussing but the most informed person as to how the topic related to others. The ability to articulate links between seemingly disparate topic areas was essential and is the well-spring of my current work.

\subsection{Russell}

Introduction: As Jan suggests, motivations are partial reasonings of decisions made (un)consciously and a good sprinkling of chance. This is a narrative of a journey through disciplinary fields, institutions, countries and cultures motivated by curiosity and commitment to examining intersections between accounting and accountability in the context of socio-ecological change. I can link these interests to childhood experiences outdoors, travels to different countries, and growing awareness of the political and ethical implications of exploitation of the environment and privatisation of public services. My interests, commonly associated with geography and sociology, were overlooked and instead I embarked on an undergraduate accounting degree in 1999 to pursue a 'safe and secure' career as an accountant. Almost twenty years later, 
I work in a management school conducting research and teaching that draws on geographical and sociological perspectives to examine new accountings and accountabilities as they are imagined and enacted in the governance of social and ecological issues (see for example Russell \& Frame 2012; Russell, Frame \& Lennox 2011; Thomson, Dey \& Russell, 2015). Here, I share insights on how critical and social and environmental accounting (SEA) has shaped my practice as a student, researcher and lecturer gleaned from key rooms and moments of my journey thus far (Le Heron, 2009).

Lecture rooms - the value of accounting education: Unlike Jan and Ian, I did not encounter SEA after working in the profession. Instead critical and SEA research featured in my undergraduate accounting degree from the University of Strathclyde. Over four years, we discussed the role of accounting - and the profession - in privatisation of public services and infrastructure (Arnold \& Cooper, 1999; Shaoul, 1997); examined alternative accounts to make visible social injustice (Cooper et al., 2005); and imagined how accounting could support sustainable development (Thomson \& Bebbington, 2005). The four years of learning were far more than an apprenticeship to the chartered accounting profession. The degree emphasised critical thinking on the social and political relevance of accounting thereby creating reflective people rather than technicians (Gendron, 2013). It awakened curiosity for ideas and cultivated a sense of possibility for social change through research, teaching and engagement with other communities (for example, accounting professionals, policy makers and social movements). My aspirations to join a Big Four firm were overturned. A job offer was jettisoned. I returned to the library to pursue a $\mathrm{PhD}$.

Libraries - the benefits of bringing together different literatures: Doctoral research provided an opportunity to delve deeper into contemporary issues, specifically the challenge of providing of safe water and sanitation, privatisation of the water sector and the implications for accountability. After many hours in libraries, critical perspectives on audit cultures and accountability regimes offered important insights into the shifting governance of the water sector (see Munro \& Mouritsen, 1996; Power, 1995). Literature from fields of geography, environmental governance and policy studies particularly that of governmentality (Dean, 1999; 2007; Foucault, 
2002) informed my analysis of neoliberal rationalities permeating the publicly owned water sector in Scotland and theorisation of accountabilities.

My doctoral experiences were liberating and daunting. On the one hand, I was inspired by views of research as a socially relevant endeavour and encouraged to engage with literature outwith the parameters of accounting research. On the other hand, as I was daunted by the realisation of the limits to which an individual researcher could inform change in policy, practice or public debates, while simultaneously publishing high quality research outputs (see also Gendron, 2013; and Hermanson, 2015). Most importantly, my original interest in sustainable management of water seemed buried under theoretical contributions and empirical examinations of an industrial sector. I wanted to step out of the library and away from disciplining effects of pursuing journal rankings and performance evaluation systems (Gendron, 2008). Instead, I wished to put socio-ecological issues at the centre of my research, to work with researchers from other disciplines and put in to practice sustainability science (see section 3.1). Hence, in 2007, I stepped out of the library and on to a plane to New Zealand to work as a post-doctoral researcher in an environmental research institution.

Meeting rooms and interdisciplinary research for sustainability: Between 2008 and 2011, I undertook qualitative research tackling sustainability-related issues as part of applied and grant-funded research programmes. Meeting rooms, riverbanks and public halls were locations for research activities working alongside ecologists, economists, geographers and political scientists. In addition, I engaged with policy makers, other practitioners and representatives from civil society. In this role, I was removed from accounting research and did not engage with the accounting profession. Instead, trying to produce credible, relevant and salient research for (and with) stakeholders that was compatible with sustainability science dominated my work. Navigating this tension between 'robust' science in order to contribute to international governance scholarship and working with communities to respond to climate change and design urban futures was not without its challenges (see section 3.3 and Cash, Clark, Alcock, Dickson ... \& Mitchell, 2003). Questions of accountability often emerged and were woven into sustainability science or practical concerns about democracy, governance and human-nature relations. Thus, questions about how 
accountability is understood and practiced in shifting regimes of environmental governance remained unanswered. The seeds of a personal research programme began to emerge. The question was where and how to realise this.

\section{Returning to lecture rooms and weaving together accounting and sustainability} transitions: After four years, I returned to Scotland keen to re-engage with core themes that sit at the heart of accounting scholarship. Upon taking up a lectureship in 2012, I have sought to juggle commitments to research, teaching and service in a university context - subject to different institutional cultures and pressures. Today, I research and engage with sustainability initiatives in universities and organisations recognising my role as a practitioner in a university as well as an academic. Critical and SEA scholarship continues to inform my work, particularly endeavours under the auspices of new accountings, through the experimentation or the examination of other accounts, and how might we reconceptualise accountability (see Contrafatto, Thomson \& Monk, 2015). In doing so, I am shifting the focus towards socioecological issues, such as climate change or water scarcity (see section 3.2 below) and ask questions about how accounting and accountabilities are understood and enacted in contested arenas (see, for example, Bebbington \& Larrinaga 2014; and Thomson et al., 2015).

\section{Summary}

Each space and moment woven together represent an account and my attempt to make sense of a career in-the-making. Tracing my path illuminates my episodic engagement with accounting scholarship where I have worked as a student, researcher and lecturer working in different institutional cultures and countries where the identity of 'an accounting academic' has been periodically adorned and cast off. Rather, I have produced research for and with various audiences where questions around how to organise, account and relate to each other and the environment were to the fore.

Upon reflection, four key insights emerge: first, my degrees cultivated a curiosity and a commitment to learn, explore, critique and engage to contribute to social change. They provided a grounding in the technical practice of accounting, as well as foundational learning about social theory and qualitative research. Second, time as doctoral and post-doctoral researcher emphasised the importance of focusing on local 
issues whilst connecting to work across disciplinary, institutional, geographical, and socio-political boundaries. Relevance here is determined by policy or publics rather than solely by debates in the academy. Third, conducting policy-orientated research has awakened an interest in relationships between research and policy and associated ethics and politics of doing so (Moran, Russell \& Wishart, 2016; Pielke Jr, 2007). Fourth, interdisciplinary work provides a more holistic understanding of socioecological issues from different philosophical and theoretical perspectives, while also bringing challenges associated with networking, publishing and career development within institutions that remain dominated by disciplines (Lyall \& Meagher, 2012).

Despite my episodic engagement with accounting research, writing this piece has strengthened my commitment to socially relevant research, which draws on, and engages with (but is not limited to) the parameters of accounting scholarship and engagement with the accounting profession. Accounting scholarship has much to offer other disciplines such as the critical examination of calculative practices that are being designed and utilised in regimes of environmental governance. It is this awareness and critical insight that I intend to continue to bring to research alongside an understanding of the intertwining of the intellectual, emotional and political interests that motivate my research. In doing so, I hope to contribute to the ethos that sits at the heart of much critical and SEA scholarship and to retain the emancipatory intention that Burawoy $(2005)^{7}$ observes can be dampened as academics progress through their career (Gendron, 2008; 2013).

\subsection{Thomson}

Introduction and a poetic interlude (in the original form and then with a translation):

O wad some Pow'r the giftie gie us

To see oursels as others see us

It wad frae monie a blunder free us

An' foolish notion

\footnotetext{
${ }^{7}$ Thanks to the anonymous reviewer who suggested reviewing Burawoy's work concerning public sociology and types of sociological labour.
} 
Oh, that God would give us the very smallest of gifts

To be able to see ourselves as others see us

It would save us from many mistakes

and foolish thoughts

Burns (1786).

This extract from Burn's satirical poem 'To a Louse' has a particular relevance to an academic career that began at a time when many branded social, environmental and critical accounting research a foolish notion. In the 1990s there was a sense of ridicule and often undisguised humour from established accounting faculty for choosing to deviate from the mainstream and with dire 'end-of-career' predictions. This tension within accounting research at that time was characterised with the Solomons - Tinker debates (Solomons, 1991; Tinker, 1991) and to a certain extent still exists today. Perhaps this is personal paranoia, but I often imagine that the laughter is simply better hidden and the mainstream are waiting for one major blunder to drum us out of the academy.

Reflecting on the choice to research SEA: My route into SEA research was 'inspired' by episodes of activism (as an accounting student and later as a public sector management accountant) against the damage inflicted on society and the environment by the foolish notions of Margaret Thatcher. My experience of bad decisions during the 1980s privatisation mania in the NHS was an important factor in a career change to academia. At that time the wages of the poorest were attacked with an ideological zeal in the name of improving organisational efficiency, ignoring the fundamental role of cleanliness, nutrition and compassion that are at the heart of effective health care. At a recent job interview I described my research as trying to understand why intelligent individuals make stupid decisions with predictable negative consequences for society and the environment (see Alvesson \& Spicer, 2012, for a further elaboration of the dynamics of functional stupidity): a stream of research unlikely ever to run dry! 
The choice of a critical approach to SEA research was confirmed and legitimated through formative experiences in conferences such as Interdisciplinary Perspectives on Accounting, Critical Perspectives on Accounting and Asia-Pacific Interdisciplinary Research on Accounting, but especially through membership of a (then) small emerging academic community of practice. Luckily for me, CSEAR was just up the road and when Rob Gray dropped by Heriot-Watt University to give a research seminar I was hooked. This led to an invite to attend the inaugural CSEAR Summer School in Dundee in 1992 with the opportunity to learn from leading accounting scholars, such as Rob Gray, David Owen, Tony Tinker, Lee Parker and Keith Maunders, who generously shared their collective expertise in environmental, social, critical and interdisciplinary accounting. There was no turning back after that. Indeed, the inspiration, kindness and generosity of the CSEAR community has carried many a SEA researcher through periods of marginalisation in their departments, protecting them from well-meaning institutional pressures to adopt conventional, narrowly defined notions of what it is to be an accounting academic. The only obligation that CSEAR asked was to pass the same support and generosity received onto others. Unfortunately, 26 years since the emergence of the CSEAR community this support is still required in certain countries and universities where non-orthodox accounting or particular research methodologies remain marginalised or suppressed.

Since then my research projects have been many and varied, inspired by things that annoy or confuse me, episodes that seem to make a difference, theories elegantly presented by others, the potential of working with fascinating individuals, combined with an enthusiasm for blundering into opportunities for engagement. With hindsight, this research strategy could be characterised as exploring critical incidents where 'sustainable' change happened, investigating the dynamics of those situations and critically reflecting on the part played by accountants, accounting, and accountability practices.

Reflecting on theory: I suspect many researchers constantly question the theorisation of their work and the work of others. I can't imagine a time when any researcher could sit back in their chair confident they won't have to read any more theoretical material, knowing they have resolved all theoretical contradictions or anomalies. For example, in relation to SEA there appear to be theoretical tensions and contractions 
between thinking about governance and accountability as being characterised by conflict; by rational, evidence-based debate; and through dialogic engagement. My internal theoretical discourse is framed and pulled in different directions through an exploration of the ideas associated with governmentality (Dean, 1999; 2007; Foucault, 2002; Rose, 1991), sociology of risk (Beck, 1992; Beck \& Wilms, 2004, Irwin, 1995; Power, 2004) and radical pedagogy (Freire, 2004; Illich, 1971) as applied to the many challenges associated with SEA (Bebbington \& Thomson, 2013; Gray, 1992, 2002, 2010; Hopwood, 2009). This internal discourse, which has been informed by other-disciplinary research on sustainable development, has yet to develop a coherent set of theoretical underpinnings or methodologies. There are, however, intersections and overlaps in the sustainable development problem space where there are possibilities to usefully synthesise ideas, concepts, observations and evidence from these bodies of work. This process of theoretical synthesis is perhaps the major forward looking challenge to SEA research. However, this synthesis will have to incorporate theorisation of power in a political programme that will disrupt the existing inequitable distribution of harms, costs, benefits, rights, obligations, wealth and resources. Whilst there is clearly a place for rational, evidence based debates and it is hard to see in the medium term an absence of conflict. At an epistemological level I find it hard to imagine sustainable development without forms of accountability that are aligned with authentic dialogic engagement processes informed by radical pedagogy of scholars such as Paolo Freire.

\subsection{Drawing reflections to a close}

Invariably, reviewers' comments on papers raise the collective game of paper writers: this paper is no exception. During review it was suggested that our personal reflections uncovered differences in positioning that may make it unlikely that we three would work well together. We found this observation fascinating (as well as surprising) and have sought to explore this proposition in more detail. In particular, we re-read our motivation statements and sought to identify commonalities as well as differences in our conceptions. Our common intellectual ground is focused around the conceptual framing we use, specifically dialogics (Freire, 2004) and governmentality (Dean, 1999; 2007). Taken together (and in outline) these framings emphasise: (i) a reflexive ongoing process of problematisation whereby one 'limit situation' creates impetus for change which eventually encounters a new 'limit situation'; (ii) a 
commitment to praxis (itself a synthesis between theory and action) where knowing and doing are an intertwined and iterative process; and (iii) a belief that co-creation of knowledge is essential. Taken together, the ontology that underlies this positioning is neither objective nor subjective. Rather, the world is seen to exist between objective and subjective moments and it is in this area of flux where change might emerge.

These common intellectual commitments flow into our propensity for engagement (in its various forms) and it is here that some differences start to emerge. In particular, on re-reading our motivations it seemed to us that where we have engaged differs. In outline, we could characterise ourselves as engaging with: (i) elites (via policy processes) to change the conditions which frame possibilities for agency; (ii) building capacity in partnership with others to engage in processes of change; and (iii) working directly with communities in the midst of change processes (in a more activist role). While each of us have experience in all these arenas there is a sense in which each of us has more experience (and/or comfort) in one mode over the other (with each mode also having its own strengths and weaknesses). As such, and despite the differences, we imagine ourselves as engaging in something akin to a three-legged race - you can move effectively (if you have to have your arms around each other) but you can also fall down plenty. We would not see this as being evidence of substantive differences/different ontologies. Rather, we would see our individual 'projects' as being synergistic and complementary, enabling us to play to our particular strengths.

In summary, we have sought to provide reasonably lengthy and messy personal reflections on motivations rather than to narrate our stories in an overly scholarly fashion. In doing this we hope that you, the reader, comes to appreciate that none of us planned what in hindsight looks at least partially coherent. Rather, we hope our stories are recognisable to others who are seeking to figure out how to 'be' in a world that invariably throws up various challenges to best laid plans. We also hope that it is evident that we have not lost motivation to continue to address issues of concern, nor have anything like 'answers' of how best to do that. The paper now moves to reflecting upon what we believe might be relevant in thinking further about accounting-sustainable development scholarship.

\subsection{Themes for current and future accounting for sustainability}


There are many aspects that we tried to assemble together in this part of the paper and after much sifting we have settled on three themes orientated around an exploration of what might be researched, how that work could be framed and with whom the work might usefully be developed.

\subsection{Problematising the problem space (what)}

Conventional accounting seems most suited to clearly defined objects, linear causeeffect relationships, single outcomes, consensus over valuation protocols and the presence of information systems. In contrast, sustainable development is a radical transformative programme, rather than a discrete object or entity. (Un)sustainability has also been conceptualised as an emergent characteristic of inter-locking social, environmental and economic systems (Bebbington \& Larrinaga, 2014; Frame, Gordon $\&$ Mortimer 2010; Sustainable Development Commission, 2011). The problem space associated with sustainable development is, therefore, loosely structured, multidimensional, multi-disciplinary, political and scientific, dynamic and characterised by complex non-linear relationships.

These characteristics complicate any exploration of SEA and accountability. Even when conceptualised as a transformative programme, there is very little consistency or coherence amongst the theories of change or policies designed to promote sustainable development. However, within the sustainable development problem space there are a number of problems that are common to most attempts to develop sustainably, and a growing consensus as to the things that need to be changed.

A recent development and synthesis in the sustainable development political programmatic discourse is the publication of the United Nations Sustainable Development Goals (SDGs) ${ }^{8}$ as part of their 2030 Agenda for Sustainable Development ${ }^{9}$. These Goals crystalise a supranational political vision of sustainable development and can form the underlying structure to map that problem space. This

\footnotetext{
${ }^{8}$ http://www.un.org/sustainabledevelopment/sustainable-development-goals/. Last accessed 16 February 2017.

${ }^{9}$ http://www.un.org/sustainabledevelopment/. Last accessed 16 February 2017.
} 
map can be viewed alongside representations of the sustainability science problem space (Bebbington \& Larrinaga, 2014; Bebbington et al., 2015).

Whilst recognising the pragmatic political process that underpins the SDGs, they also have considerable potential as a framework for SEA and accountability. The Goals might also offer a way round the inertia caused by claims of the lack of a generally accepted conceptually coherent definition of sustainable development. Our view is that, whilst not perfect, the SDGs are sufficiently radical to inform SEA research. Table One lists the SDGs (and the future vision inherent in them) as well as offering the counterpoint to their ambitions in the first column in the form of the "unsustainable development goals' in order to highlight what outcomes you end up with if you don't aim for different outcomes.

\begin{tabular}{|c|c|c|}
\hline \multicolumn{3}{|c|}{ Table One: the un-sustainable development goals and the UN Sustainable Development Goals } \\
\hline & Un-sustainable development goals & $\begin{array}{l}\text { United Nations Sustainable Development } \\
\text { Goals }\end{array}$ \\
\hline 1. & Perpetuate poverty in all its forms & End poverty in all its forms \\
\hline 2. & $\begin{array}{l}\text { Maintain hunger, food insecurity, poor } \\
\text { nutrition levels whilst maintaining } \\
\text { unsustainable agriculture }\end{array}$ & $\begin{array}{l}\text { End hunger, achieve food security \& } \\
\text { improved nutrition \& promote sustainable } \\
\text { agriculture }\end{array}$ \\
\hline 3. & $\begin{array}{l}\text { Continue with health inequality \& lack of } \\
\text { wellbeing for all at all ages }\end{array}$ & $\begin{array}{l}\text { Ensure healthy lives \& promote wellbeing for } \\
\text { all at all ages }\end{array}$ \\
\hline 4. & $\begin{array}{l}\text { Perpetuate levels of inaccessibility to quality } \\
\text { education \& provision of limited lifelong } \\
\text { learning opportunities, even in developed } \\
\text { world }\end{array}$ & $\begin{array}{l}\text { Ensure inclusive \& equitable quality education } \\
\& \text { promote lifelong learning opportunities for } \\
\text { all }\end{array}$ \\
\hline 5. & $\begin{array}{l}\text { Maintain gender inequality \& oppression of } \\
\text { women \& girls }\end{array}$ & $\begin{array}{l}\text { Achieve gender equality \& empower all } \\
\text { women \& girls }\end{array}$ \\
\hline 6. & $\begin{array}{l}\text { Perpetuate limited access to \& existing } \\
\text { approaches to management of water \& } \\
\text { sanitation }\end{array}$ & $\begin{array}{l}\text { Ensure availability \& sustainable management } \\
\text { of water \& sanitation for all }\end{array}$ \\
\hline 7. & $\begin{array}{l}\text { Restrict access to unaffordable, unreliable, } \\
\text { hydrocarbon based modern energy for some }\end{array}$ & $\begin{array}{l}\text { Ensure access to affordable, reliable, } \\
\text { sustainable \& modern energy for all }\end{array}$ \\
\hline 8. & $\begin{array}{l}\text { Promote destructive economic growth for } \\
\text { some, maintaining exploitative employment } \\
\text { practices particularly in developing countries }\end{array}$ & $\begin{array}{l}\text { Promote sustained, inclusive \& sustainable } \\
\text { economic growth, full \& productive } \\
\text { employment } \& \text { decent work for all }\end{array}$ \\
\hline 9. & $\begin{array}{l}\text { Invest in the same infrastructure, promoting } \\
\text { short-term profitability \& industrialisation }\end{array}$ & $\begin{array}{l}\text { Build resilient infrastructure, promote } \\
\text { inclusive \& sustainable industrialisation \& } \\
\text { foster innovation }\end{array}$ \\
\hline 10. & $\begin{array}{l}\text { Maintain inequality within \& among } \\
\text { countries }\end{array}$ & Reduce inequality within \& among countries \\
\hline 11. & $\begin{array}{l}\text { Maintain risky, fragile, unequal access to } \\
\text { cities \& human settlements }\end{array}$ & $\begin{array}{l}\text { Make cities \& human settlements inclusive, } \\
\text { safe, resilient \& sustainable }\end{array}$ \\
\hline 12. & $\begin{array}{l}\text { Maintain socially, ecologically \& } \\
\text { economically damaging consumption \& } \\
\text { production }\end{array}$ & $\begin{array}{l}\text { Ensure sustainable consumption \& production } \\
\text { patterns }\end{array}$ \\
\hline
\end{tabular}




\begin{tabular}{|c|l|l|}
\hline 13. & $\begin{array}{l}\text { Ignore the potential damage from climate } \\
\text { change \& its impacts }\end{array}$ & $\begin{array}{l}\text { Take urgent action to combat climate change } \\
\text { \& its impacts }\end{array}$ \\
\hline 14. & $\begin{array}{l}\text { Exceed the regenerative capacity of the } \\
\text { oceans, seas \& marine resources }\end{array}$ & $\begin{array}{l}\text { Conserve \& sustainably use the oceans, seas } \\
\text { \& marine resources for sustainable } \\
\text { development }\end{array}$ \\
\hline 15. & $\begin{array}{l}\text { Exceed the regenerative capacity of the } \\
\text { terrestrial ecosystems, forests, land \& } \\
\text { biodiversity }\end{array}$ & $\begin{array}{l}\text { Protect, restore \& promote sustainable use of } \\
\text { terrestrial ecosystems, sustainably manage } \\
\text { forests, combat desertification, halting \& } \\
\text { reversing land degradation, biodiversity loss }\end{array}$ \\
\hline 16. & $\begin{array}{l}\text { Allow conflicts to remain unresolved, } \\
\text { perpetuate exclusion \& partial access to } \\
\text { justice, breaching human rights, operating } \\
\text { within problematic, unaccountable systems } \\
\text { of governance }\end{array}$ & $\begin{array}{l}\text { Promote peaceful \& inclusive societies for } \\
\text { sustainable development, provide access to } \\
\text { justice for all, building effective, accountable, } \\
\text { inclusive institutions at all levels }\end{array}$ \\
\hline 17. & $\begin{array}{l}\text { Allow existing weaknesses in Global } \\
\text { Partnership for Sustainable Development } \\
\text { (GPSD) to persist. }\end{array}$ & $\begin{array}{l}\text { Strengthen the means of implementation \& } \\
\text { revitalise the GPSD. }\end{array}$ \\
\hline
\end{tabular}

A full articulation of how the SDGs may play out in accounting and accountability terms is beyond the scope of this paper. However, one example is developed below to illuminate these points. In this example, accounting emerges from the Goals in contrast with seeking to find niches where some accounting practice/technique might illuminate the Goals. The example also illustrates the need to reconsider accounts, accountings and accountabilities in connection with the sustainability of freshwater.

Recently, accounting scholarship has begun to examine the design and implementation of accounting practices for freshwater in part motivated by concerns about water scarcity and climate change. For example Egan (2014) highlights the limits to efforts to establish water accountability systems alongside financial accountability within an organisational entity, while Tello, Hazelton \& Cumming (2016) note the tension between water accounts relating to freshwater catchments and the accounts produced by those organisations that are responsible for freshwater. In both instances, authors make the links between concerns for water scarcity and social, economic and ecological outcomes of water management before returning to central themes of accounting and accountability. Perhaps this is sufficient in light of the continued imperative to contribute to the substantive theorisation of accounting as a social and institutional practice (Hopwood, 2009) and a need and wish to engage with academic audiences.

The water governance problem space, however, illustrates that SEA scholars do not have to wait for domains to be 'tamed', such as through the legislative establishment 
of accounting systems, in order to investigate them. Recognising the loosely structured, multi-dimensional, multi-disciplinary, political and scientific context of freshwater management, the SDG Goal number six (ensuring access to water and sanitation for all) provides a frame in which to examine accounting and accountability. This Goal is designed to ensure availability and sustainable management of water and sanitation for all. So one question we might ask is: how might one design and implement an accounting and accountability system to support this goal? What accountabilities are currently in play in freshwater management and how might they be adapted to meet the Goal?

Taking a sustainability science approach to examine accounts, accounting and accountability for freshwater, one might need to first orientate research towards defining a problem space and only then consider the accounting and accountability implications that arise. This process is unlikely to be the responsibility of researchers alone. In this problem space many accounts, accountings and accountabilities are present but invisible, often dominated by corporate accounts of GRI water indicators or the creation of water managers' 'performance' reports. For example, in seeking to understand strategic water resource management, one might additionally examine narrative accounts from landowners, recreationalists and local councils in order to create an understanding of the problem space.

In seeking to understand the problem space, we are also unlikely to focus on communications from (corporate) entities engaged in using or managing water (albeit that exploring these accounts remains a valuable activity). Instead, we might seek to understand the accountability relationships and practices between organisational actors and physical entities (water catchments and river systems, for example); places where knowledge is formulated; sites of evaluation and experimentation; and modes of accountability (via political, legal, governance and informal means).

This approach, therefore, requires us to 'zoom out' from a conventional focus on corporate entities to consider the myriad of other actors involved in freshwater. All of these elements combine to affect any accounting project and, taken together, would constitute a space where accountability might be understood and interrogated. To do this work, accounting scholars are likely to have to work with others to construct 
deliberative accounting or accountability technologies to frame the examination of different strategic scenarios in the context of the accountability relationships between different parties (see Lennox, Proctor \& Russell, 2011; Russell, et al., 2011). This placing of accounting within a wider accountability frame is reflective of a sustainability science approach and leads to the question of how better to distinguish accounting and accountability.

\subsection{Accounting and accountability: contrasting perspectives (how)}

It is evident from the preceding section that a sustainable development-accounting hybrid requires a focus on a problem issue enmeshed in a wider ecological, social and economic context. This leads to the issue of identifying the particular aspect of the problem set that accounting scholarship can contribute to, as well as, how the accounting aspects are co-determined by other elements in the overall system. This is a very different approach to discipline based scholarship which leads to the question being asked: 'where is the accounting' or 'where is the novel theoretical framing for this question' - see Guthrie and Parker (2017) for a discussion of these challenges. What we would prefer to ask of our work is: 'where is the sustainable development'?

Moreover, questions of 'where is the accounting' are especially problematic if one takes 'accounting' to be the sub-set of research activities that are championed by a North American research tradition. Not surprisingly such a question (and the intellectual framing behind such a question) narrows the array of possible research topics as well as over simplifying accounting questions. This tendency to focus down on (rather than open up) a problem space is not unique to accounting - such tendencies are also evident in management research. For example, Lunnenluecke \& Griffiths (2013: 382) note that business research has failed to engage with "pressing issues such as climate change", and when it does the terms of engagement are those that emerge from a "relatively narrow research scope" (ibid, and see also Goodall, 2008) informed by management thinking, not climate thinking.

One way in which to counter this tendency, we would propose, is to identify a focus on accounting as emerging from the discipline (that is, accounting is the means) but to elaborate and understand accounting within a wider field of study of accountability 
(as the end that the accounting links to). An interest in accountability has been evident in accounting scholarship for many years (for a small sample, see Meyer, 1986; Munro \& Mouritsen, 1996; Roberts, 1991). The concept of accountability, however, has not always been well received and criticisms have focused on how accountability has been sought by powerful interests (focusing, for example, on narrowly drawn measures of performance). This approach to accountability often manifests as a focus on corporate accounting practices supporting the abuse of power (Clegg, 1989) with unsustainable consequences (Roberts, 1996). These criticisms are 'just' given the interpretations of accountability evident in the literature and in practice. These interpretations, however, are not the only way to enact accountability and attempts to create more nuanced and enabling forms of accounting remain a valid aspiration.

Indeed, exploring examples of the use of alternative accounting and accountability practices in assemblages of activist practices that appeared to subvert the power of orthodox accounting (Beck \& Wilms, 2004; Cooper et al., 2005) points to possibilities for weaker groups in society to make their story heard to those abusing their power or to those unaware of their suffering. These desires are supported in other disciplinary literature - see, for example, Bovens, Schillemens \& Hart (2008); Dean (2007) and Foucault (2002). Accountability, therefore, is characterised as offering insights into understanding the potential of accounting as a transformative, emancipatory force rather than a word to describe the grudging, partial disclosures designed to maintain the self-interest of corporations, governments and regulators and their control over others (Bebbington, Brown, Frame \& Thomson, 2007; Gray, 2002, 2010; Roberts, 1991, Thomson \& Bebbington, 2005). Indeed, we would argue that accountability capacities and accounting-like practices are distributed widely throughout society and are not constrained by the technology, rationality, conventions or history of the accountancy profession (Grandvoinnet, Aslam \& Raha, 2015). Accountabilities in these spaces are less concerned with calculative rationality, encompassing multicentric accountabilities (Joss, 2012) while still striving for representational faithfulness and a form of 'truth'. This creates the potential for an accounting that creates compelling and holistic narratives that can include facts, evidence and costs, but only when those preparing the accounts consider them relevant (Brown \& Dillard, 2013b; Joshi \& Moore, 2004). 


\subsection{Conceptualising a scholarly and political project of engagement (with whom)}

Engagement with practice communities has animated much SEA and critical accounting research (Adams \& Larrinaga-González, 2007; Cooper, 2002; Cooper \& Coulson, 2013; Correa \& Larrinaga 2015; Deegan, 2013; Dillard \& Vinnari, 2017) along with discussions of the benefits of undertaking such work (see, for example, Hermanson, 2015). At the same time, unease remains about the form of engagement that may be adopted, how one might engage, and the implications of such engagement (Deegan, 2013). Risks associated with engagement could include risk of capture by commercial interests, critique from peers about collaboration with perceived 'enemies', or dealing with institutional pressure to generate impact whilst also producing internationally leading theoretically original work (Adams \& LarrinagaGonzález, 2007).

As academic performance management regimes expand to take account of research impact, the question of whether to engage or not may become redundant (Gendron, 2008; Hopwood, 2009). Beyond succumbing to the pressures of performance management (Gendron 2008) and seeking to engage with others to comply as an academic performer, we summarise two perspectives that seek to make sense of engagement in order to contribute to ongoing debates about engagement as part of academic performance.

First, Martin's (2010) research-practitioner engagement typology from the field of public management aids understanding of how academics may wish to engage with others where practitioners may be informants or recipients, commissioners or coresearchers. Each configuration of researchers and practitioners presents risks and opportunities. For example, when practitioners act as informants or recipients researchers can maintain 'relational distance' in order to safeguard academic freedom (hence protecting from risk of capture). However, this distance may mean that these findings are not utilised. In contrast, as commissioners, practitioners may politicise research findings while also increasing chances that the research may inform practice. Where practitioners are co-researchers working across almost every stage of the research, the differences between parties are blurred, if not fully erased (often described as co-production). This approach recognises that research is a collective, 
rather than a lone, endeavour and can ensure that research findings are relevant to practitioner audiences. This approach has been criticised for creating confusion about the boundaries, identities and responsibilities of parties involved (Jung, Harrow \& Pharoah, 2012; Nutley, 2010). It has been suggested that 'researchers' and 'others' need to take account of the power and politics at play and develop reflexive practice by examining their own assumptions in order to "generate openness to alternatives and to others' interests, perspectives and approaches" (Orr \& Jung, 2016: 213-214).

Second, developing a political and scholarly project of engagement prompt questions of 'research for whom?' and 'research for what?'. The typology of sociological labour as articulated by Burawoy (2005) provides a helpful heuristic for recognising the diversity of ways in which we might characterise academic work. Burawoy describes four types of sociology (professional, public, policy and critical - see Table Two). Reviewing SEA and critical accounting scholarship, we find examples of research that has sought to: (i) contribute to understanding of theoretical knowledge in accounting (professional - see, Bebbington \& Larrinaga, 2014); (ii) engage with policy communities (including the accounting profession) and parliamentarians to change policy or with organisations to change practice (policy - see, Cooper et al., 2005); (iii) examine and critique accounting as a social and institutional practice contributing to debates in the accounting academy (critical - see, Gray, 2010); and (iv) illuminate accounting's power to wider audiences (public - see, Contrafatto et al., 2015). Rather than frame engagement solely around answering policy or practice questions as suggested by an instrumental approach to research, those wishing to conduct engaged research also need to interrogate value premises and assumptions of society and the academy through reflexive forms of knowledge production (Bebbington et al., 2007; Correa \& Larrinaga, 2015). Furthermore, Burawoy's work conveys an appreciation of each approach and a recognition of their interdependence.

\begin{tabular}{|l|l|l|}
\hline Table Two: Typologies of accounting 'work' (adapted from Burawoy, 2005) \\
\hline & Research for whom? \\
\hline Research for what? & Academic & Extra-academic \\
\hline Instrumental (puzzle solving, answering policy questions) & Professional & Policy \\
\hline
\end{tabular}




\begin{tabular}{|l|l|l|}
\hline $\begin{array}{l}\text { Reflexive (dialogue interrogating value premises of society } \\
\text { and academia) }\end{array}$ & Critical & Public \\
\hline
\end{tabular}

Rather than viewing engagement as arising when we (the academics) specifically engage with non-academics, we suggest that it is more helpful to recognise the diversity of engagement opportunities. This is pertinent when undertaking sustainability research where working with others (including other academic disciplines) to engage in instrumental puzzle solving alongside reflexive interrogation of the value premises of society is the norm. Nevertheless, echoing past debates about the risk of conformity and superficiality in accounting research due to institutional pressures on academic performance, it is important that we continue to discuss, debate and critically reflect on knowledge, practice, engagement and the discourses, identities and practices that are shaping and being shaped by engagement in order to understand everyday worlds in academia, policy and practice (Orr \& Jung, 2016).

While many SEA and critical accounting researchers are committed to informing practice and have experience in doing so, the insights do not often feature in pages of accounting journals. As far as we are aware, little has been written in Critical Perspectives on Accounting that is explicitly identified as arising from co-production, although there are some examples of creating research with others or attempting to inform social movements and policy (see Bebbington \& Gray, 2001; Contrafatto, et al., 2015; Cooper, 2002; Gibbon, 2012; Larrinaga-González \& Bebbington, 2001).

In order to ground some of this discussion, Table Three (in the format of a vignette) outline an engagement undertaken by Bebbington. In doing so, the vignette is a product of a reflexive examination of our own assumptions and making visible the political processes at play in order to enrich our understanding of engagement (as inspired by Orr \& Bennett, 2009). If one were to seek evidence of this engagement in an academic terms it would not be readily apparent beyond a generic description of having held a policy role; a note of funding received to support the work and a one page summary in a professional journal (the Geographer - the magazine of the Royal Scottish Geographical Society - Bebbington, 2011). The engagement generated a report (Carnegie UK Trust \& Sustainable Development Commission, 2011) that does 
not have named authors, albeit that the input of those who wrote and supported the work is acknowledged. The type of engagement undertaken (in the form of chairing a Round Table) and the lack of evidence of the impact of the work illuminates some of the inherent complexity of interrogating engagement (that is, the vignette is in Freirean terms, problem posing).

\section{Table Three: An example of engagement (Bebbington) \\ A brief description: \\ From 2006 until 2011 I held a public policy role as the Vice Chair (Scotland) of the Sustainable Development Commission (SDC). The SDC was an advisory Non-Departmental Public Body whose role was to promote sustainable development across the UK and all sectors of society, particularly within Government. The role was a one day a week appointment (by way of competitive interview and via a public appointments process) where I was as a 'commissioner' (one of up to 18 commissioners covering regions or topics - such as economics, food, energy) supported by a secretariat (of up to 60 people - who were formally civil servants).}

As part of my role in that organisation (and building on earlier work by Jackson, 2009) I was asked to co-chair a Round Table to consider the relevance of the 'Sarkozy Commission' (Stiglitz, Sen, \& Fitoussi, 2009) for Scotland and to inform a particular element of Scottish Government practice (the shape of its National Performance Framework - see http://www.gov.scot/About/Performance/scotPerforms - last accessed 27/06/2017). The Sarkozy Commission was an initiative of the French Government in 2008 to problematise the reliance on GDP for a proxy of economic and social progress. Their Report was influential in policy domains and the Scottish Round Table was conceived of as a way to bring their findings into the Scottish political context in a more customised way: 12 recommendations for Scottish Government action were made. Round Table members were all participants in various aspects of political and civil society, including: the ex-Permanent Secretary of the Scottish Government; those with experience in senior Government agency roles (for example, the Scottish Environmental Protection Agency, the Human Rights and Equalities Commission and the Accounts Commission for Scotland); those with relevant academic expertise in economics; those operating at a senior level in business, voluntary organisations and local authorities; as well as a columnist from a national newspaper. At the same time as the Round Table reported, other Scottish focused publications were produced that also focused on this agenda (for example, Dunlop \& Trebeck, 2012 and Wallace \& Schmuecker, 2012).

\section{A reflection:}

Several observations can be offered on the basis of this engagement:

Form: the engagement involved co-hosting a process in order to develop a policy facing piece of work (with speaking at a public event associated with the Report launch). In keeping with a sustainability science focus, the work was aimed at a particular country (Scotland) and its policy needs at that time. 
Audience: the report was aimed at the Scottish Government (primarily) with meetings held to discuss the report with policy makers. In addition, those interested in the themes of the work were also a target audience: we hoped our work would support their ability to be effective in their work. Further, and under the guise of building capacity, the audience also included those who were members of the Round Table and the organisations they were members of.

Impact: the impact of this work is not readily identifiable (nor would it be easy to track any impact). The report and process likely supported a general awareness (alongside other initiatives) within Scotland of the themes being considered. One side effect of the work was to reinforce a network of contacts within Scottish society (and especially senior level networks of influence - which can be critically important in small countries) between members of the group. I have certainly used these contacts for other activities and have been drawn into other activities by members of the Round Table. The inclusion of a journalist in the Round Table was self-conscious as it created opportunities for changing the nature of public discourse. It is not clear if the report made any specific impact on the Government nor if it prevented something from happening that might have otherwise changed.

Capture: it is not clear to me how this process or outcome could have been characterised as captured by interest groups (although it clearly might have been).

Link to the academy: the work was not explicitly identified as an academic output nor was this work of the nature of that identified as 'impact' in the United Kingdom's Research Evaluation Framework exercise (which focuses on the impact of academic research outputs). The work built my knowledge in this area that has flowed over to a nascent interest in economic democracy (Bebbington \& Campbell, 2015) but is otherwise not connected with my academic work.

Accounting relevance: I am a lay reader of this economic/policy field but not an academic expert. While themes from the accounting literature (focused on dysfunctional measurement systems, commensuration and performativity) are cognate to the Round Table topic, this was not accounting discipline specific work.

This section has focused on posing problems for the future, focusing on what we might research (we would argue on substantive social, environmental and economic issues captured, for example, in the SDGs); how we could frame that work (with us suggesting that accountability might be more generative than accounting); and exploring with whom engagement might be pursued (where we sought to provide a wider lens on engagement activities).

\subsection{Concluding observations}

It is our contention that sustainable development is a radical ambition; that it is something to get passionate about and is also deliciously complex, multi-dimensional and transdisciplinary (Frame et al., 2010). The research possibilities are endless as 
sustainable development requires exploring the intersections between academic disciplines; theory and practice; past and the present; practice and politics; the weak and the powerful; nature and humanity; aesthetics and science; emotions and rationality; utopias and dystopias. Accounting-like practices and accounting-like actors are situated in many of these boundaries and require critical analysis as to their roles and impact, whether good, bad or indifferent (Beck, 1992; Dean, 1999; Oels, 2005; Power, 2004; Rose, 1991).

If we accept that sustainable development is a socio-political programme, then the entities for SEA and accountability should relate to the challenges, problems, structures, systems, obstacles and conflicts associated with unsustainability in all its guises (Bebbington \& Thomson, 2007; Oels, 2005). It is also necessary to account for the interdependencies and relationships amongst these different entities, informed by the scientific and political programmatic discourses associated with sustainable development. This requires accountants, and others in power, recognising the capacity and rights of others in society to provide legitimate accounts and participate in the governance of issues that impact on their lives and their environment.

One way that accountability could develop is through the idea of the 'citizen accountant' and 'citizen accountability' working in collaboration with the idea of the 'citizen scientist' and 'citizen science' (Hand, 2010; Irwin, 1995). Citizen science or public participation blurs the boundary between the expert and the lay individual recognising everyone's gifts, skills and capacity for exploring, analysis, collection of facts and stories and finding ways of representing critical aspects of our existential realities and feasible alternative ways of being (Seiber, 2006; Wynne, 1996). The potential for authentic social and environmental accountability through organised crowd-sourced participation accessible to all citizens with a stake in a sustainable future is under explored. Our collective experience of engaging with organisations (in both the public and private sector), activists, political institutions, charities, regulators and communities suggests that alternative accounts could have a significant impact in reducing the number of stupid decisions taken, challenging foolish notions of those in power and avoiding many a blunder. As critical and SEA researchers we could have a part to play in organising, inspiring, building capacity and facilitating this participation in the radical socio-political programme of sustainable development. 
In all of these endeavours, there is considerable benefit in making ourselves understandable to ourselves (through, for example, papers such as this one); to SEA and critical accounting colleagues (who are most likely readers of this journal); to colleagues in more mainstream accounting traditions as well as other scholars focused on organising and organisations; to scholars in other disciplines (such as those working in governance as well as to physical scientists); as well as those working to enact the changes on the ground that we would see as being necessary for sustainable development transitions. We hope that this contribution enlivens these interactions.

Acknowledgements: We would like to acknowledge the helpful comments of and support from Christine Cooper and Yves Gendron. 


\section{References:}

Adams, C. \& Larrinaga-González, C. (2007). Engaging with organisations in pursuit of improved sustainability accounting and performance. Accounting, Auditing \& Accountability Journal, 20(3), 333-355.

Alvesson, M. \& Spicer, A. (2012). A stupidity-based theory of organizations. Journal of Management Studies, 49(7), pp. 1194-1220.

Arnold, P. \& Cooper, C. (1999). A tale of two classes: the privatisation of Medway ports. Critical Perspectives on Accounting.

Bebbington, J. (2016). The St Andrews Sustainability Institute: fostering sustainability in a cold climate, in Papa, R. \& Saiti, A. eds, Building for a Sustainable Future in Education: Brick by Brick. New York: Springer. pp. 35-44.

Bebbington, J. (2011). It matters what matters to Scotland, The Geographer, Summer, pp.9.

Bebbington, J., Brown, J., Frame, B. \& Thomson, I. (2007). Theorizing engagement: the potential of a critical dialogic approach. Accounting, Auditing and Accountability Journal, 20(3), 356-381.

Bebbington, J. \& Campbell, D. (2015). Economic democracy: exploring the ramifications for social and environmental accountants. Social and Environmental Accountability Journal, 35(2), pp. 77-85.

Bebbington, J. \& Gray, R. (2001). An account of sustainability: failure, success and a reconceptualisation. Critical Perspectives on Accounting, 12(5), 557-605.

Bebbington, J. \& Larrinaga, C. (2014). Accounting and sustainable development: an exploration. Accounting, Organizations and Society, 39 (6), 395-413.

Bebbington, J., Larrinaga, C., Russell, S. \& Stevenson, L. (2015). Organizational, management and accounting perspectives on biodiversity. Biodiversity in the Green Economy. Gasparatos, A. \& Willis, K. (eds.). Abingdon: Routledge, p. 213-239.

Bebbington, J. \& Thomson, I. (2007). SEA, auditing and reporting: a potential source of organizational risk governance? Environment and Planning C, 25(1), 38-55.

Bebbington, J. \& Thomson, I. (2013). Sustainable development, management and accounting: boundary crossing. Management Accounting Research, 24(4), 277-283.

Beck, U. (1992). Risk Society: Towards a New Modernity. London: Sage Publications.

Beck, U. \& Willms, J. (2004). Conversations with Ulrich Beck. Cambridge, UK: Polity Press. 
Bovens, M., Schillemans, T. \& Hart, P. (2008). Does public accountability work? An assessment tool. Pub Admin, 86(1), 225-242.

Bowen, H. (1953). Social Responsibilities of the Businessman. New York: Harper.

Brown, J. \& Dillard, J. (2013a). Agonizing over engagement: SEA and the "death of environmentalism" debates. Critical Perspectives on Accounting, Vol. 24(1), 1-18.

Brown, J. \& Dillard, J. (2013b). Critical accounting and communicative action: on the limits of consensual deliberation. Critical Perspectives on Accounting, 24(3), 176190.

Burawoy, M. (2005). For public sociology. American Sociological Review, 70(1), pp. 4-28.

Burns, R. (1786) To a Louse, available at www.robertburns.org/97.shtml

Carnegie UK Trust and Sustainable Development Commission (2011). More than GDP: Measuring What Matters: Report of the round Table on Measuring Economic Performance and Social Progress in Scotland. Edinburgh: Carnegie UK Trust.

Cash, D., Clark, W., Alcock, F., Dickson, N., Eckley, N., Guston, D., Jäger, J. \& Mitchell, R. (2003). Knowledge systems for sustainable development. Proceedings of the National Academy of Sciences, 100(14), 8086-8091.

Chua, W. F. (1986). Radical developments in accounting thought. The Accounting Review, LXI(4), pp. 601-632.

Clegg, S. (1989). Frameworks of Power. London: Sage Publications.

Contrafatto, M., Thomson, I. \& Monk, E. (2015). Peru, mountains and los niños: dialogic action, accounting and sustainable transformation. Critical Perspectives on Accounting, 33, 117-136.

Cooper, C. (2002). Critical accounting in Scotland. Critical Perspectives on Accounting, 13(4), 451-462

Cooper, C. (2005). Accounting for the public interest: public ineffectuals or public intellectuals? Accounting, Auditing and Accountability Journal, 18(5), 592-607.

Cooper, C. \& Coulson, A. (2014). Accounting activism and Bourdieu's 'collective intellectual' - Reflections on the ICL Case. Critical Perspectives on Accounting, 25(3), 237-254.

Cooper, C., Taylor, P., Smith, N. \& Catchpowle, L. (2005). A discussion of the political potential of social accounting. Critical Perspectives on Accounting, 16(7), 951-974.

Correa, C. \& Larrinaga, C. (2015). Engagement research in social and environmental accounting. Sustainability Accounting, Management and Policy. 
Dean, M. (1999). Governmentality: Power and Rule in Modern Society. London: Sage Publications.

Dean, M. (2007). Governing Societies. Berkshire: Open University Press.

Deegan, C. (2013). The accountant will have a central role in saving the planet ... really? A reflection on 'green accounting and green eyeshades twenty years later'. Critical Perspectives on Accounting, 24(6), 448-458.

Dillard, J. \& Brown, J. (2012). Agonistic pluralism and imagining CSEAR into the future, Social and Environmental Accountability Journal, 32(1), 3-16.

Dillard, J. \& Brown, J. (2015). Broadening out and opening up: an agonistic attitude toward progressive social accounting, Sustainability Accounting, Management and Policy Journal, 9(2), pp. 243-66.

Dillard, J. \& Vinnari, E. (2017). A case study of critique: critical perspectives on critical accounting. Critical Perspectives on Accounting, 43(1), 88-109.

Dunlop, S. \& Trebeck, K. (2012). The Oxfam Humankind Index for Scotland: The new measure of Scotland's prosperity. London: Oxfam.

Egan, M. (2014). Making water count: water accountability change within an Australian university. Accounting, Auditing \& Accountability Journal, 27(2), 259282.

Foucault, M. (2002) Power, Penguin, London.

Freire, P. (2004) Pedagogy of the Oppressed, 30th Anniversary Edition. New York: The Continuum International Publishing Group.

Frame, B., Gordon, R. \& Mortimer, C. (2010) Hatched: Capacity for Sustainable Development, Landcare Research, New Zealand.

Gendron, Y. (2008). Constituting the academic performer: the spectre of superficiality and stagnation in academia. European Accounting Review, 17(1), 97-127.

Gendron, Y. (2013). Accounting academia and the threat of the paying-off mentality. Critical Perspectives on Accounting, 26(1), 1-9.

Ghaye, T., Melander-Wikman, A., Kisare, M., Chambers, P., Bergmark, U., Kostenius, C. \& Lillyman, S. (2008). Participatory and appreciative action and reflection (PAAR) - democratizing reflective practices. Reflective Practice, 9(4), pp. 361-397.

Gibbon, J. (2012). Understandings of accountability: an autoethnographic account using metaphor. Critical Perspectives on Accounting, 23(3), 201-212. 
Godemann, J., Bebbington, J., Herzig, C. \& Moon, J. (2014). Higher education and sustainable development: exploring possibilities for organisational change. Accounting, Auditing and Accountability Journal, 27(2), 218-233.

Goodall, A. (2008). Why have the leading journals in management (and other social sciences) failed to respond to climate change? Journal of Management Inquiry, 17, 408-420.

Grandvoinnet, H., Aslam, G. \& Raha, S. (2015). Opening the Black Box: The contextual drivers of social accountability. World Bank Group.

Gray, R. (1992). Accounting and environmentalism: an exploration of the challenge of gently accounting for accountability, transparency and sustainability. Accounting Organisations and Society, 17(5), 399-425.

Gray, R. (2002). The social accounting project and Accounting Organizations and Society. Privileging engagement, imaginings, new accountings and pragmatism over critique? Accounting Organisations and Society, 27(7), 687-708.

Gray, R. (2010). Is accounting for sustainability actually accounting for sustainability... and how would we know? An exploration of narratives of organisations and the planet, Accounting Organisations and Society, 35(1), 47-62.

Gray, R., Bebbington, J. \& Gray, S., (2010), SEA (Vols I - IV), (Sage: London).

Gray, R. \& Laughlin, R. (2012). It was 20 years ago today: Sgt Pepper, Accounting, Auditing \& Accountability Journal, green accounting and the Blue Meanies, Accounting, Auditing and Accountability Journal, 25(2), 228-255.

Gray, R., Owen, D. \& Adams C. (1996). Accounting and accountability. Hemel Hempstead: Prentice Hall.

Gray R., Owen, D. \& Maunders, K. (1987). Corporate Social Reporting: Accounting and accountability. Hemel Hempstead: Prentice Hall.

Guthrie, J. \& Parker, L. (2017). Reflections and projections: 30 years of the interdisciplinary accounting, auditing and accountability search for a fairer society. Accounting, Auditing \& Accountability Journal, 30(1), 2-17.

Hand, E. (2010). Citizen science: people power, Nature, 466, 685-687.

Hermanson, D. (2015). "Model 2" - a personal journey in pursuit of creativity and impact. Critical Perspectives on Accounting, 26, 130-140.

Hopwood, A. (2009). Accounting and the environment. Accounting, Organizations and Society, 34 (3-4), 433-439.

Hopwood, A., Unerman, J. \& Fries, J. (2010). Accounting for Sustainability:

Practical Insights. London: Earthscan. 
Hugé, J., Block, T., Waas, T., Wright, T. \& Dahdouh-Guebas, F. (2016). How to walk the talk? Developing actions for sustainability in academic research. Journal of Cleaner Production, 137(1), pp. 83-92.

Illich, I. (1971). Deschooling society. New York: Harper Row.

Irwin, A. (1995). Citizen Science: A Study of people, expertise and sustainable development. London: Routledge.

Jackson, T. (2009). Prosperity Without Growth: Economics for a Finite Planet. London: Earthscan.

Joshi, A. \& Moore, M. (2004). Institutionalised co-production: unorthodox public service delivery in challenging environments. Journal of Development Studies, 40(4), $31-49$.

Joss, S. (2010). Accountable governance, accountable sustainability? A case study of accountability in the governance for sustainability. Environmental Policy \& Governance. 20: 408-421.

Jung, T., Harrow, J. \& Pharoah, C., (2012). Co-producing research: working together or falling apart? CGAP Briefing Note 8, Centre for Charitable Giving \& Philanthropy, Cass Business School City University London. Available http://www.cgap.org.uk/uploads/Briefing\%20Papers/CGAP\%20Briefing\%20Note\%2 08\%20-\%20Co-producing\%20research.pdf (Accessed 18 February 2017).

Larrinaga-Gonzáles, C. \& Bebbington, J. (2001). Accounting change or institutional appropriation? - a case study of the implementation of environmental accounting. Critical Perspectives on Accounting, 12(3), 269-292.

Le Heron, R. (2009). 'Rooms and moments' in neoliberalising policy trajectories of metropolitan Auckland, New Zealand: towards constituting progressive spaces through post-structural political economy. Asia Pacific Viewpoint, 50(2), 135-153.

Lennox, J., Proctor, W. \& Russell, S. (2011). Structuring stakeholder participation in New Zealand's water resource governance. Ecological Economics, 70(7), 1381-1394.

Loads, D. \& Campbell, F. (2015). Fresh thinking about academic development: authentic, transformative, disruptive? International Journal for Academic Development, 20(4), pp. 355-369.

Lunnenluecke, M. \& Griffiths, A. (2013). Firms and sustainability: mapping the intellectual origins and structure of the corporate sustainability field. Global Environmental Change, 23, 382-391.

Lyall, C. \& Meagher, L. (2012). A masterclass in interdisciplinarity: research into practice in training the next generation of interdisciplinary researchers. Futures, 44(6), pp. 608-617. 
Martin, S. (2010). Co-production of social research: strategies for engaged scholarship, Public Money \& Management, 30 (4), 211-218.

Meyer, J. (1986). Social environments and organizational accounting. Accounting, Organizations and Society, 11(4/5), 345-356.

Moran, C., Russell, S. \& Wishart, L. (2016). Negotiating knowledge through boundary organisations. In Orr, K., Bain, R., Hacking, B., Moran, C., Nutley, S. \& Russell, S. (eds.). Knowledge and Practice in Business and Organisations. New York: Routledge.

Munro, R. \& Mouritsen, J. (1996). Accountability: Power, Ethos \& the Technologies of Managing. London: International Thomson Business Press.

Nutley, S. (2010). Debate: Are we all co-producers of research now? Public Money and Management. 30(5): 263-265

NZGS-PG Network (2014), Postgraduates performing powerfully in a changing academic environment. New Zealand Geographer, 70: 61-68. doi:10.1111/nzg.12020

Oels, A. (2005). Rendering climate change governable: From biopower to advanced liberal government?, J of Env Pol Plan, 7(3), 185-207.

Orr, D. (2004). Earth in Mind: On Education, Environment and the Human Prospect. Washington: Island Press.

Orr, K. \& Bennett, M. (2009). Reflexivity in the co-production of academicpractitioner research. Qualitative Research in Organizations and Management, 4 (1), 85-102.

Orr, K. \& Jung, T. (2016). Coproducing knowledge and practice. In K. Orr, S. Nutley, R. Bain, B. Hacking, \& S. Russell (Eds.), Knowledge and Practice in Business and Organisations. Routledge. 201-215.

Patterson, J., Lukasiewicz, A., Wallis, P., Rubenstein, N., Coffey, B., Gachenga, E. W. \& Lynch, A. (2013). Tapping fresh currents : fostering early-career researchers in transdisciplinary water governance research. Water Alternatives, 6(2), 293-312.

Pielke Jr., R. (2007) The honest broker: making sense of science in policy \& politics. Cambridge: Cambridge University Press.

Power, M. (1995). Auditing, expertise and the sociology of technique. Critical Perspectives on Accounting, 6(4), 317-339.

Power, M. (2004). The Risk Management of Everything: Rethinking the Politics of Uncertainty. London: Demos.

Raneri, N. (2015) Business doctoral education as a liminal period of transition: comparing theory and practice. Critical Perspectives on Accounting, 26(1), 99-107. 
Roberts, J. (1991). The possibilities of accountability, Accounting, Organizations and Society, 16(4), 355-368.

Roberts, J. Ed. (1996). From Discipline to Dialogue: Individualizing and Socializing Forms of Accountability. Accountability: Power, Ethos and the Technologies of Managing. London, International Thompson Business Press.

Rose, N. (1991). Governing by numbers: figuring out democracy. Accounting, Organizations and Society, 16(7), 673-693.

Russell, S. \& Frame, B 2013 Technologies for sustainability: a governmentality perspective. International Journal of Sustainable Development. 16 (1), pp. 91-106.

Russell, S., Frame, B. \& Lennox, J., 2011 Old Problems New Solutions: navigating water governance. Lincoln: Landcare Research New Zealand Ltd.

Russell, S. \& Thomson, I. (2009). Analysing the role of sustainable development indicators in accounting for and constructing a Sustainable Scotland. Accounting Forum, 33(3), 225-244.

Saravanamuthu, K. (2015). Instilling a sustainability ethos in accounting education through the transformative learning pedagogy: A case-study. Critical Perspectives on Accounting, 32(1), pp. 1-36.

Seiber, R. (2006). Public participation geographic information systems: a literature review and framework. Ann Assoc American Geographer, 96(3), 491-507.

Shaoul, J. (1997). A critical financial analysis of the performance of privatised industries: the case of the water industry in England and Wales. Critical Perspectives on Accounting, 8(5), 479-505.

Schatzki, T. (2012) A primer on practices, in J. Higgs, R. Barnett, S. Billett, M. Hutchings, \& F. Trede (eds.), Practice-based education: Perspectives \& strategies. Rotterdam: Sense Publishers, pp. 13- 26.

Solomons, D. (1991). Accounting and social change: a neutralist view. Accounting, Organizations and Society, 16(3), 287-295.

Spence, L. \& Rinaldi, L. (2014). Governmentality in accounting and accountability: A case study of embedding sustainability in a supply chain. Accounting, Organizations and Society, 39(6), 433-452.

Stiglitz, J., Sen, A. \& Fitoussi, J. (2009). Report by the Commission on the Measurement of Economic and Social Progress.

Sustainable Development Commission (2011). Prosperity without growth: the transition to a sustainable economy. London: Sustainable Development Commission. 
Tello, E., Hazelton, J. \& Cummings, L. (2016). Potential users' perceptions of general purpose water accounting reports. Accounting, Auditing \& Accountability Journal, 29(1), 80-110.

Thomson, I. \& Bebbington J. (2004). It doesn't matter what you teach? Critical Perspectives on Accounting, 15(4/5), 609-628.

Thomson, I. \& Bebbington J. (2005). "Social and environmental reporting in the UK: a pedagogic evaluation", Critical Perspectives on Accounting, 16(5), 507-533

Thomson, I., Grubnic, S. \& Georgakopoulos, G. (2014). Exploring accountingsustainability hybridisation in the UK public sector. Accounting, Organizations and Society, 39 (6), 453-476.

Thomson, I., Dey, C. \& Russell, S. (2015). Activism, arenas and accounts in conflicts over tobacco control. Accounting, Auditing \& Accountability Journal, 28(5), 809845 .

Tinker, T. (1991). The accountant as partisan, Accounting, Organizations and Society, 16(3), 297-310.

Unerman, J. \& Chapman, C. (2014). Academic contributions to enhancing accounting for sustainable development. Accounting, Organizations and Society, 39(6), 385-394.

Wallace, J. \& Schmuecker, K. (2012). Shifting the Dial: From wellbeing measures to policy practice. Dunfermline: Carnegie UK Trust.

Wynne, B. (1996). May the sheep safely graze? A reflexive view of the expert-lay knowledge divide, in Lash S., Szerszinski, B. \& Wynne, B. (eds), Risk, Environment and Modernity: Towards a New Ecology. London: Sage, pp $44-83$. 